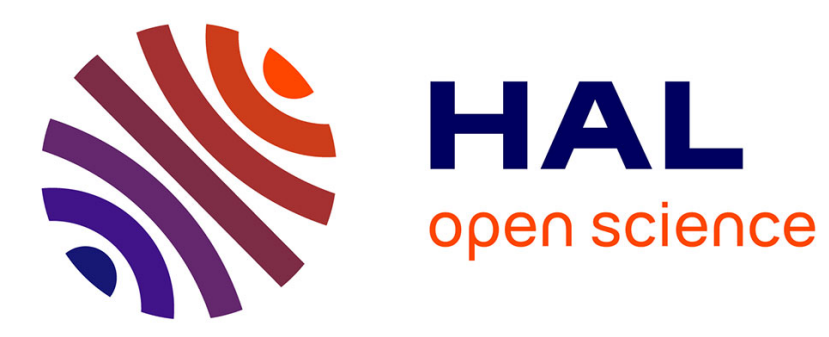

\title{
Modelling the climate evolution from the last interglacial to the start of the last glaciation: The role of Arctic Ocean freshwater budget
}

M. Khodri, Gilles Ramstein, D. Paillard, J. Duplessy, M. Kageyama, A. Ganopolski

\section{To cite this version:}

M. Khodri, Gilles Ramstein, D. Paillard, J. Duplessy, M. Kageyama, et al.. Modelling the climate evolution from the last interglacial to the start of the last glaciation: The role of Arctic Ocean freshwater budget. Geophysical Research Letters, 2003, 30 (12), 10.1029/2003GL017108 . hal-02930154

\section{HAL Id: hal-02930154 \\ https://hal.science/hal-02930154}

Submitted on 9 Oct 2020

HAL is a multi-disciplinary open access archive for the deposit and dissemination of scientific research documents, whether they are published or not. The documents may come from teaching and research institutions in France or abroad, or from public or private research centers.
L'archive ouverte pluridisciplinaire HAL, est destinée au dépôt et à la diffusion de documents scientifiques de niveau recherche, publiés ou non, émanant des établissements d'enseignement et de recherche français ou étrangers, des laboratoires publics ou privés. 


\title{
Modelling the climate evolution from the last interglacial to the start of the last glaciation: The role of Arctic Ocean freshwater budget
}

\author{
M. Khodri, ${ }^{1}$ G. Ramstein, D. Paillard, J. C. Duplessy, and M. Kageyama \\ Laboratoire des Sciences du Climat et l'Environnement, Gif sur Yvette, France \\ A. Ganopolski \\ Potsdam Institute for Climate Impact Research (PIK), Potsdam, Germany \\ Received 11 February 2003; revised 11 February 2003; accepted 25 March 2003; published 18 June 2003.
}

[1] The Earth's climate has alternated between glacial and interglacial stages, but we still do not understand how the changes in insolation have been amplified by the climate system to lead to such a large climatic response. Here we use a climate model of intermediate complexity to show that the orbitally induced shift from an interglacial to a preglacial climate is highly sensitive to the high northern latitudes moisture budget. Using the insolation forcing alone, the model produces a first order response of sea surface temperatures and thermohaline circulation evolution which agrees with the available geological data. Under the same gradual insolation evolution, adding a small freshwater input into the Arctic Ocean induces a rapid climate switch from an interglacial to a pre-glacial mode. These results suggest a simple connection between orbital forcing and the thermohaline circulation through a freshwater threshold within the ocean-atmosphere-sea-ice system. INDEX TERMS: 3344 Meteorology and Atmospheric Dynamics: Paleoclimatology; 3309 Meteorology and Atmospheric Dynamics: Climatology (1620); 3339 Meteorology and Atmospheric Dynamics: Ocean/atmosphere interactions (0312, 4504); 4267 Oceanography: General: Paleoceanography; 1620 Global Change: Climate dynamics (3309). Citation: Khodri, M., G. Ramstein, J. C. Duplessy, M. Kageyama, D. Paillard, and A. Ganopolski, Modelling the climate evolution from the last interglacial to the start of the last glaciation: The role of Arctic Ocean freshwater budget, Geophys. Res. Lett., 30(12), 1606, doi:10.1029/2003GL017108, 2003.

\section{Introduction}

[2] How seasonal and latitudinal variations of the incident solar radiation initiate internal feedbacks that produce a shift from an interglacial to a glacial mode is still a matter of debate. Studies based on Atmospheric General Circulation Models (AGCMs) forced by modern sea surface temperatures (SSTs) or coupled to mixed layer ocean [Phillipps and Held, 1994; Rind et al., 1989], have not been successful in simulating perennial snow cover, while accounting for ocean and vegetation feedbacks has produced results in better agreement with proxy records [de Noblet et al., 1996; Khodri et al., 2001]. Nevertheless, beyond the Milankovitch theory that argues for an orbitally induced shift from an

\footnotetext{
USA.

${ }^{1}$ Now at Lamont-Doherty Earth Observatory, Palisades, New York,
}

Copyright 2003 by the American Geophysical Union. 0094-8276/03/2003GL017108 interglacial to a glacial climate, the available proxy records give important clues that have still not been fully explored through modelling studies. Recent work from North Atlantic sediment cores clearly identifies a cooling step correlated to a significant change in deep water circulation around 115 kyr BP [Shackleton et al., 2002; Adkins et al., 1997; Hall et al., 1998]. There is more evidence, from both land and marine records, for an "intra-Eemian" cooling event in the high latitudes of the Northern Hemisphere around 120 kyr BP [Cortijo et al., 1999; Sánchez-Goñi et al., 1999; Tzedakis et al., 2002]. It appears that this early "cold reversal" within the Eemian was associated to low salinity values in the Northern Seas [Cortijo et al., 1999] and to a significant shallowing of North Atlantic Deep Water [Maslin et al., 2001]. Superimposed to those abrupt events, on longer time scales there is an increasing trend in the NADW production during Marine Isotope Stage 5e [Duplessy and Shackleton, 1985]. After the mid-Eemian cold reversal, it seems that the NADW recovers, but the climate warming does not return to full interglacial conditions before the second cooling step, $115 \mathrm{kyr}$ BP, which marks the beginning of the latest glacial stage. However, during the whole last interglacial period mid- to low latitudes surface ocean temperatures remain warm [McManus et al., 2002].

[3] The lag between insolation forcing and northern high latitudes cooling extrema at $120 \mathrm{kyr}$ BP emphasises the necessity of exploring the mechanisms responsible for the changes occurring through the last interglacial and their implication for the last glacial inception. We propose to explore this issue by combining an Earth system Model of Intermediate Complexity (EMIC), a coupled ocean-atmosphere GCM (OAGCM), and the comparison to paleoclimatic data. First, we simulated the climate evolution from the stable interglacial (126 kyr BP) to the period of major ice sheet build-up (115 kyr BP) and to compare the results to data. For this, we use CLIMBER-2 [Petoukhov et al., 2000] forced only with the evolution of the orbital parameters between those two dates (Table 1). Second, since OAGCM results have shown the importance of the ocean in amplifying the initial insolation forcing [Khodri et al., 2001], we performed sensitivity experiments to determine the thresholds in freshwater that may convert the insolation decrease of $115 \mathrm{kyr}$ BP into a maximum northern high latitudes cooling.

\section{Results and Discussion}

[4] The increasing axial tilt and gradual shift of the date of perihelion into the winter months from $126 \mathrm{kyr} \mathrm{BP}$ to 115 
Table 1. Orbital Parameters of the Earth Used in the Simulations for Incoming Solar Radiation Calculation at the Top of the Atmosphere

\begin{tabular}{cccc}
\hline Month & Control & 115 kyr BP & 126 kyr BP \\
\hline Eccentricity & 0.016724 & 0.041421 & 0.04 \\
Obliquity (axial tilt ${ }^{\circ}$ ) & 23.446 & 22.404 & 23.928 \\
Perihelion $-180^{\circ}\left({ }^{\circ}\right)$ & 102.04 & 111.01 & 291.24 \\
$\mathrm{CO}_{2}(\mathrm{ppm})$ & 280 & 280 & 280 \\
\hline
\end{tabular}

The transient experiment starts with the initial conditions of a $126 \mathrm{kyr} \mathrm{BP}$ equilibrium experiment and is run for 11000 years with the corresponding orbital parameters varying according to Berger [1978]. The present day simulation is referred to as the control run. For all the simulations, the concentration of the atmospheric $\mathrm{CO}_{2}$ is kept at its pre-industrial level, as shown in the Vostok records [Raynaud et al., 1993].

kyr BP induces a progressive decrease of the summer insolation at the high latitudes of the Northern Hemisphere (Figures 1a and 1c) and an increase in insolation during winters, centred in the subtropical latitudes. The summer SSTs over the North Atlantic (at $75^{\circ} \mathrm{N}$ ) cool by $1.2^{\circ} \mathrm{C}$ in summer and by $0.8^{\circ} \mathrm{C}$ in annual mean, while the low latitude annual mean SSTs remain roughly unchanged, since the winter warming counterbalances the summer cooling (Figures 1e and 1f). In the mean time, in response to the decreasing summer insolation forcing, the sea-ice melt is progressively reduced, leading to an extension and thickening of Arctic Ocean sea-ice, reaching a plateau at $120 \mathrm{kyr}$ BP (not shown). The associated albedo increases by about $10 \%$ during this time period, enhancing the orbitally-forced cooling in northern high latitudes (Figures $1 \mathrm{a}-1 \mathrm{f}$ and caption). Therefore, the high latitude SSTs are at their coolest early within the last interglacial thanks to the seaice albedo increase, in agreement with the SSTs inferred from North Atlantic marine sediment cores [Cortijo et al., 1999]. This first order response to the insolation forcing simulated by CLIMBER-2 provides a possible explanation for the early Eemian cooling. However, the model does not succeed in simulating any abrupt cold reversal and shallowing of NADW neither at $120 \mathrm{kyr}$ BP or at $115 \mathrm{kyr}$ BP.

[5] Instead, during the simulated last interglacial, the coupled ocean-atmosphere system responds to the orbital forcing by enhancing the northward heat transport by both the ocean and atmosphere. The strength of the thermohaline circulation (THC) increases from $126 \mathrm{kyr}$ BP to $120 \mathrm{kyr}$ BP and then remains constant and vigorous until $115 \mathrm{kyr}$ BP (Figure 1g). The stronger THC increases the amount of heat transported northward by the Atlantic Ocean during this time period (by $7.5 \%$ ) and the atmospheric maximum northward heat transport, at $115 \mathrm{kyr} \mathrm{BP}$, experiences a $6.5 \%$ increase mainly due to the dry static heat component. Both the increased ocean and atmospheric northward heat transports are driven by the equator-to-pole insolation gradient. Between $126 \mathrm{kyr}$ and $120 \mathrm{kyr} \mathrm{BP}$, the total fresh water flux into the Arctic Ocean decreases by 0.01 Sverdrup (Sv) mainly because of decreased precipitation (Table 2 and caption). This leads to an increase in salinity of Arctic waters (Figures $2 \mathrm{a}-2 \mathrm{c}$ ), which gradually penetrate in the Greenland-Iceland-Norwegian (GIN) seas, inducing higher winter deep mixing rate at $120 \mathrm{kyr}$ BP (Figure $1 \mathrm{~g}$ ). In the meantime, the subtropical SSTs warm during winter because of the solar forcing. At $120 \mathrm{kyr} \mathrm{BP}$, in response to the
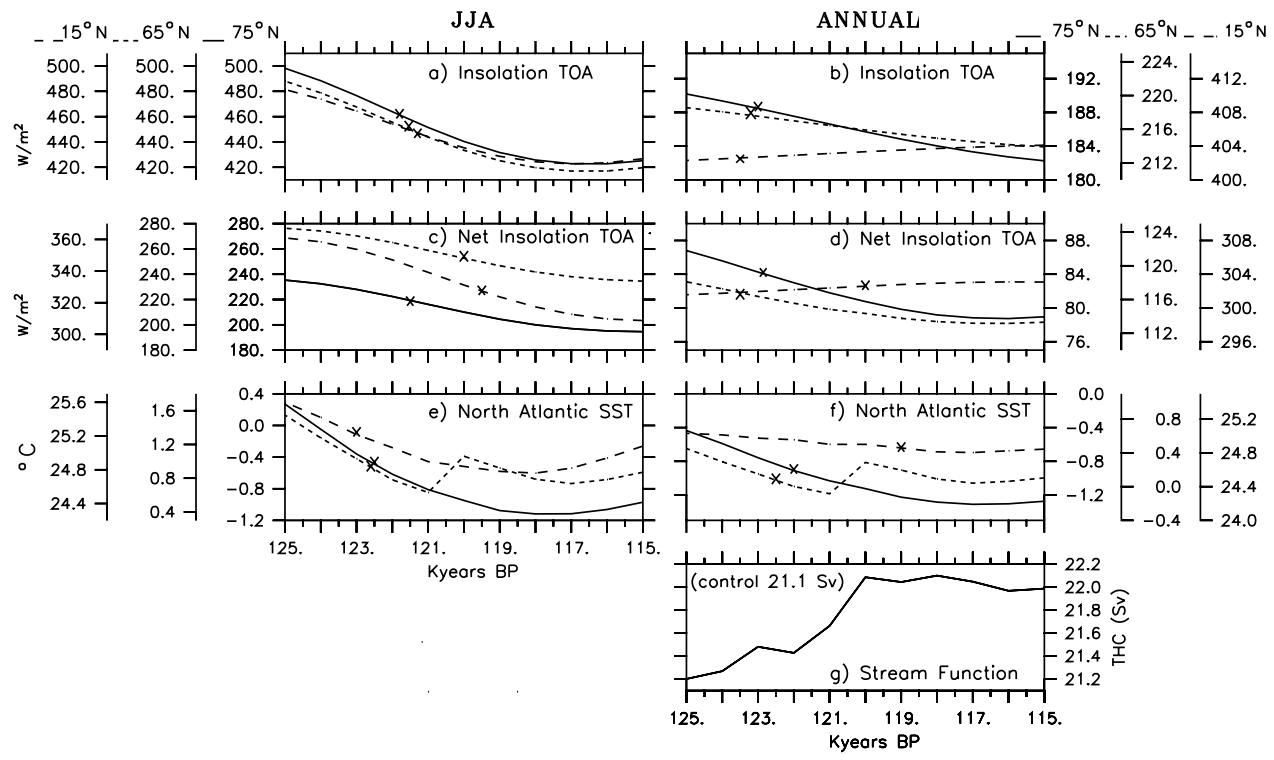

Figure 1. Time series of the North Atlantic Sea Surface Temperature (SST) and thermohaline circulation strength (THC) in response to changing insolation forcing at the top of the atmosphere (TOA) between $125 \mathrm{kyr}$ BP and $115 \mathrm{kyr}$ BP. a-b, June-July-August (JJA, a) and Annual mean (b) of incoming solar radiation at the top of the atmosphere at $15^{\circ} \mathrm{N}$ (dashed curve), $65^{\circ} \mathrm{N}$ (dotted curve) and $75^{\circ} \mathrm{N}$ (solid curve) in $\mathrm{W} / \mathrm{m}^{2}$ [Berger, 1978]. c-d, The same as in a,b but for the net values at the top of the atmosphere simulated by CLIMBER-2; e-f, June-July-August (JJA, e) and Annual mean (f) of North Atlantic SSTs at $15^{\circ} \mathrm{N}$ (dashed curve), $65^{\circ} \mathrm{N}$ (dotted curve) and $75^{\circ} \mathrm{N}$ (solid curve) in ${ }^{\circ} \mathrm{C}$. g, Evolution of the annual mean values of intensity of the THC in Sverdrup $\left(\mathrm{Sv}\right.$, i.e. $\left.10^{6} \cdot \mathrm{m}^{3} \cdot \mathrm{s}^{-1}\right)$. In $\mathbf{a}-\mathbf{f}$, the corresponding value for the control is indicated by a cross. The value of intensity of the THC for the control run is also indicated in $\mathbf{g}$. By comparing the rate of summer insolation decrease at $75^{\circ} \mathrm{N}, 65^{\circ} \mathrm{N}$ and at $15^{\circ} \mathrm{N}(\mathbf{a}-\mathbf{d})$, the rate (the first derivative) of cooling is twice more rapid in high latitudes than to lower latitudes. 
Table 2. Freshwater Budget Evolution in the Arctic Ocean in Response to the Changing Insolation of the Last Interglacial

\begin{tabular}{lcccc}
\hline $\begin{array}{c}\text { Sverdrups } \\
\text { (Sv) }\end{array}$ & $126 \mathrm{kyr}$ BP & $120 \mathrm{kyr} \mathrm{BP}$ & $115 \mathrm{kyr} \mathrm{BP}$ & $\begin{array}{c}115 \mathrm{kyr} \mathrm{BP} \mathrm{m} \\
126 \mathrm{kyr} \mathrm{BP}\end{array}$ \\
\hline P-E & 0.107 & 0.102 & 0.098 & -0.009 \\
Runoff & 0.085 & 0.088 & 0.089 & +0.004 \\
Net ice melting & -0.026 & -0.03 & -0.031 & -0.005 \\
Total & $\mathbf{0 . 1 6 6}$ & $\mathbf{0 . 1 6}$ & $\mathbf{0 . 1 5 6}$ & $-\mathbf{0 . 0 1}$ \\
\hline
\end{tabular}

During the transient experiment the precipitation minus evaporation (P-E) becomes the major operating distillation process. Indeed, the water distillation rate by sea-ice freezing, due to increased sea-ice export from production area $(-0.005 \mathrm{~Sv}$ from $126 \mathrm{kyr} \mathrm{BP}$ to $115 \mathrm{kyr} \mathrm{BP})$ is compensated by the increased runoff $(+0.004 \mathrm{~Sv})$.

increased ocean meridional overturning, the warmer surface waters reach the deep convection sites (Figures 2d-2f). Then, the competition between the increased salinity and the warmer surface temperatures at the deep convection sites leads to a self-stabilised THC from $120 \mathrm{kyr}$ BP to 115 kyr BP (Figure 1g). The warming effect of the increased northward ocean heat transport affects surface temperatures as far as $65^{\circ} \mathrm{N}$ at $120 \mathrm{kyr} \mathrm{BP}$ (Figures $1 \mathrm{e}-1 \mathrm{f}$, and Figure 2f). As shown on Figures 1e-1f, at $120 \mathrm{kyr}$ BP, during summer, there is indeed a step up of SST at $65^{\circ} \mathrm{N}$. This excursion to warmer temperatures during summer illustrates a short attempt of the ocean heat transport to go further north in response to the strengthened THC which peaks at $120 \mathrm{kyr}$ BP. However it is immediately followed by a decrease in temperature because of the summer insolation decrease and the sea ice extent feedbacks. In annual mean, the decreasing high latitude SSTs therefore meanly reflect the summer response.

[6] According to the data reviewed in the introduction section there is indeed a small global trend of increased production of NADW during the stage 5e [Duplessy and Shackleton, 1985] in agreement with our results and with those of Wang and Mysak [2002] who used another EMIC. The THC and SSTs changes simulated here therefore seem realistic. However, there is no snow accumulation over Northern Hemisphere continent and no abrupt cooling associated to a reduced THC at $120 \mathrm{kyr}$ BP nor at 115 kyr BP. The crude land surface resolution in CLIMBER, and in EMICS in general, might explain why we do not obtain snow nucleation over Northern Hemisphere continents. Also, the present model does not include a coupling

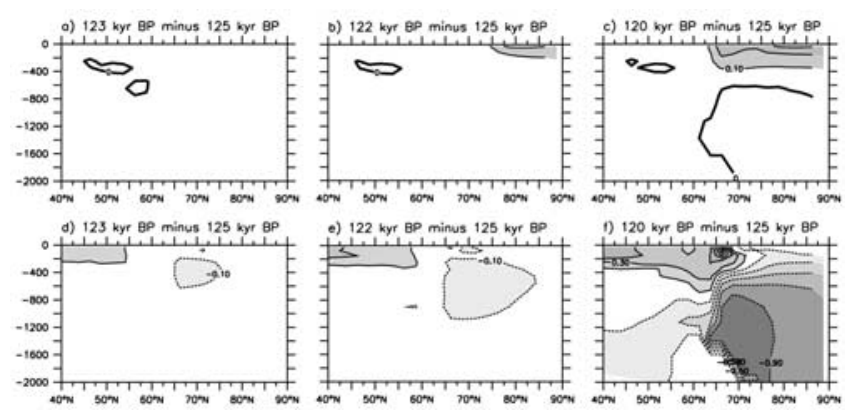

Figure 2. Response of the winter North Atlantic salinity and temperature to changing insolation forcing. Latitudedepth distribution of January-February means of the salinity in $\operatorname{PSU}(\mathrm{a}, \mathrm{b}, \mathrm{c})$ and temperature in ${ }^{\circ} \mathrm{C}$ in the North Atlantic (d, e, f).
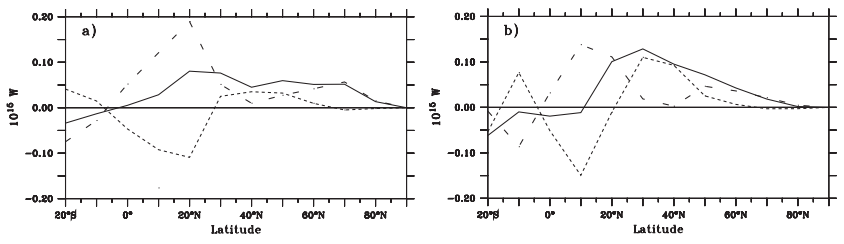

Figure 3. (a) Annual mean zonal average difference between $115 \mathrm{kyr}$ BP and control simulations of the atmospheric heat transport in PW, for total (solid line), dry static (dashed line) and latent heat (dotted line) simulated by CLIMBER-2. (b) Same as (a) but obtained by the IPSL model [Khodri et al., 2001].

to an ice-sheet model, which could help in starting a glaciation.

[7] Using a finer grid OAGCM forced by the $115 \mathrm{kyr}$ BP insolation, Khodri et al. [2001] have shown that the surface ocean cooling north of $60^{\circ} \mathrm{N}$, the Arctic sea ice extension, the southward shift of the polar front and the shallowing of the NADW, help maintain perennial snow over the Canadian Archipelago. This reorganisation, due to a positive feedback operating via the increased atmospheric moisture transport from the warmer tropical ocean to the northern seas therefore corroborates the data which demonstrate such an event at 115 kyr BP [Shackleton et al., 2002; Adkins et al., 1997; Hall et al., 1998]. In both the transient interglacial EMIC simulation and the snapshot OAGCM simulation, the increased meridional gradient of SSTs leads to an enhanced northward atmospheric heat transport; but, at $115 \mathrm{kyr}$ BP in the transient simulation the annual mean atmospheric heat transport at about $30^{\circ} \mathrm{N}$ is almost half that in the OAGCM simulation (0.07 PW and $0.13 \mathrm{PW}$ respectively), and is mainly represented by the dry static heat $(71.4 \%$ vs. $30 \%$ for the OAGCM simulation, Figure 3). The smaller increase of northward atmospheric moisture transport in the EMIC $(+0.03 \mathrm{~Sv})$ compared to the OAGCM $(+0.06 \mathrm{~Sv})$, is not large enough to induce a decrease of THC at $115 \mathrm{kyr} \mathrm{BP}$ (Figure 3). Therefore small variations of the hydrologic cycle over the North Atlantic may have dramatic consequences. Since Cortijo et al. [1999] also reported a freshening of the Northern oceans from $120 \mathrm{kyr}$ BP until $115 \mathrm{kyr}$ $\mathrm{BP}$, it seems that the hydrological cycle response in CLIMBER is too weak to capture such an event. Moreover, Cuffey and Marshall [2000] also argue that the sea level rise during the last interglacial was partly due to meltwater from Greenland. As the version of CLIMBER-2 used here is not coupled to an ice sheet model, this might also explain why the model, when only forced by the orbital parameters does not reproduce the mid-Eemian cold reversal.

[8] To explore such a sensitivity to the freshening of the Northern Seas, we increased the northward atmospheric moisture transport by about $0.03 \mathrm{~Sv}$ at $115 \mathrm{kyr} \mathrm{BP}$ in the EMIC simulation, to mimic the OAGCM results. In this sensitivity experiment, the THC weakens, as obtained in the OAGCM simulation and perennial snow over Northern Canada is simulated (not shown). This last result shows that both the OAGCM and the EMIC lead to the same simulated climate when applying the same hydrological cycle changes. To identify the threshold at which such a reversal is achieved, in an other sensitivity experiment, the freshwater transport by the atmosphere from low to high 


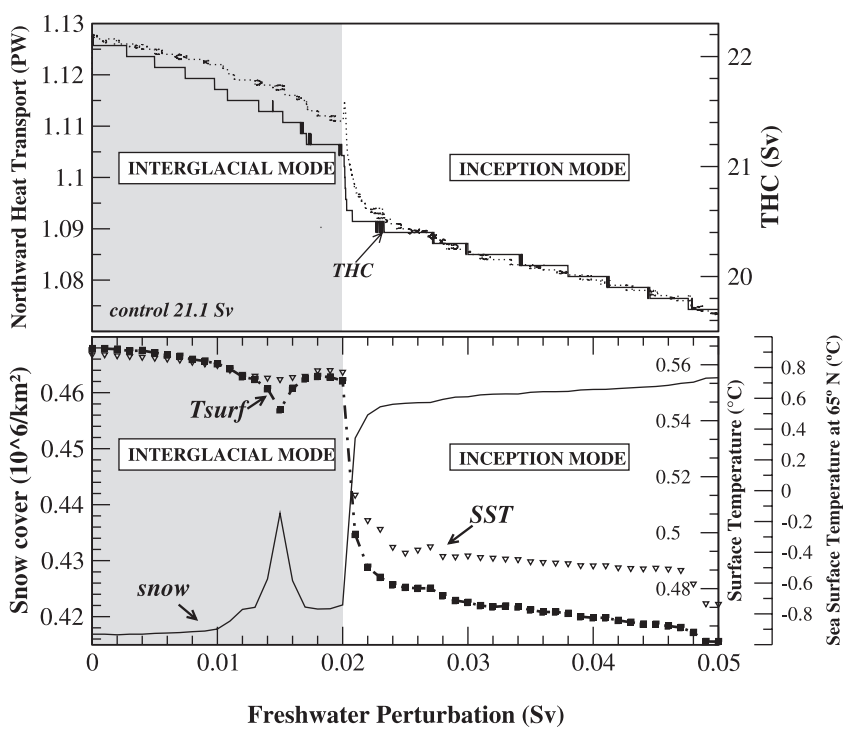

Figure 4. Response of the THC, Maximum Atlantic Northward heat transport (top panel) to freshwater supply $(\mathrm{Sv}, \mathrm{x}$ axis) in the northern seas and the impact (bottom panel) over the Atlantic SSTs at $65^{\circ} \mathrm{N}$, the northern Canada surface temperature and snow cover $\left(70^{\circ}-80^{\circ} \mathrm{N}\right)$ at $115 \mathrm{kyr}$ BP. In this sensitivity experiment, the freshwater transport by the atmosphere from low to high latitudes is progressively increased from 0 to $0.05 \mathrm{~Sv}$.

latitudes is progressively increased from 0 to $0.05 \mathrm{~Sv}$ in the climate simulated by CLIMBER at $115 \mathrm{kyr}$ BP (Figure 4). At $0.015 \mathrm{~Sv}$, there is a short reversal in land surface temperature and snow cover which corresponds to a first attempt for the climate to shift to a colder mode. From this result we can suppose that the mid-Eemian cooling recorded by the data may have been such an attempt, since according to environmental reconstructions, the climate that followed this event did not return to full interglacial conditions. But the most important results lies into the non-linear response of the simulated climate at $115 \mathrm{kyr} \mathrm{BP}$ to the freshwater forcing. Indeed, when the small threshold in freshwater input of $0.02 \mathrm{~Sv}$ into high latitude ocean is reached, the climate switches abruptly from an interglacial mode with warm high latitudes temperatures and snow melted in summer over northern Canada to a pre-glacial mode characterised by cooler land, perennial snow cover and weakened THC (Figure 4).

[9] We have shown that the maximum cooling in North Atlantic ocean is achieved before the minimum of summer insolation as recorded by data thanks to the sea-ice albedo feedbacks. However, to obtain a North Atlantic freshening and cooling at $115 \mathrm{kyr} \mathrm{BP}$, consistent with the data and to the OAGCM simulation it is necessary to amplify the hydrological cycle. Here, we did not consider the ice sheet feedback, but our results show that such an interaction could have important impacts through land ice melting and albedo effects. We are currently developing the model with which we will be able to study such interactions.

[10] Acknowledgments. We would like to thank Dr. Elsa Cortijo for helpful discussions and the anonymous referee for their constructive comments. We also thank the Potsdam Institute for Climate Impact Research (PIK) for providing us the CLIMBER-2 model. This is LSCE contribution 0908 .

\section{References}

Adkins, J. F., E. A. Boyle, L. Keigwin, and E. Cortijo, Variability of the North Atlantic thermohaline circulation during the last interglacial period, Nature, 390, 154-156, 1997.

Berger, A. L., Long-term variations of daily insolation and Quaternary climatic change, J. Atmos. Sci., 35, 2362-2367, 1978.

Cortijo, E., S. Lehman, L. Keigwin, et al., Changes in meridional temperature and salinity gradients in the North Atlantic Ocean $\left(30^{\circ}-72^{\circ} \mathrm{N}\right)$ during the last interglacial period, Paleoceanography, 14(1), 23-33, 1999.

Cuffey, K. M., and S. J. Marshall, Substantial contribution to sea-level rise during the last interglacial from the Greenland ice sheet, Nature, 404, $591-594,2000$.

de Noblet, N., I. C. Prentice, S. Joussaume, et al., Possible role of atmosphere-biosphere interactions in triggering the last glaciation, Geophys. Res. Lett., 23, 3191-3194, 1996.

Duplessy, J. C., and N. J. Shackleton, Response of global deep-water circulation to Earth's climatic change $135,000-107,000$ years ago, Nature, $316,500-507,1985$

Hall, I. R., N. McCave, M. R. Chapman, and N. J. Shackleton, Coherent deep flow variation in the Iceland and American basins during the last interglacial, Earth Planet. Sci. Lett., 164, 15-21, 1998.

Khodri, M., et al., Simulating the amplification of orbital forcing by ocean feedbacks in the last glaciation, Nature, 410, 570-574, 2001.

Marshall, S. J., and G. K. C. Clarke, Ice-sheet inception: Subgrid hypsometric parameterization of mass balance in an ice sheet model, Clim. Dyn., 15, 533-550, 1999.

Maslin, M., D. Seidov, and J. Lowe, Synthesis of the nature and causes of rapid climate transitions during the Quaternary, in The Oceans and Rapid Climate Change: Past, Present, and Future, Geophys. Monogr. Ser, vol. 126, edited by M. Maslin, pp. 9-52, AGU, Washington, D. C., 2001.

McManus, J. F., et al., Thermohaline circulation and prolonged interglacial warmth in the North Atlantic, Quat. Res., 58, 17-21, 2002.

Petoukhov, V., et al., CLIMBER-2: A climate system model of intermediate complexity. part I: Model description and performance for present climate, Clim. Dyn., 16, 1-17, 2000.

Phillipps, P. J., and M. Held, The response to orbital perturbations in a atmospheric model coupled to a slab ocean, J. Clim., 7, 767-782, 1994. Raynaud, D., et al., The ice record of greenhouse gases, Science, 259, $926-$ 934, 1993

Rind, D., D. Peteet, and G. Kukla, Can Milankovitch orbital variations initiate the growth of ice sheets in a general circulation model?, J. Geophys. Res., 94, 12,851-12,871, 1989.

Sánchez Goñi, M. F., F. Eynaud, J. L. Turon, and N. J. Shackleton, High resolution palynological record off the Iberian margin: Direct land-sea correlation for the Last Interglacial complex, Earth Planet. Sci. Lett., 171, $123-137,1999$.

Shackleton, N. J., et al., The classic Marine Isotope Substage 5e, Quat. Res., 58, 14-16, 2002.

Tzedakis, P. C., M. R. Frogley, and T. H. Heaton, Duration of the last interglacial conditions in northwestern Greece, Quat. Res., 58, 53-55, 2002.

Wang, Z., and L. A. Mysak, Simulation of the last glacial inception and rapid ice sheet growth in the McGill Paleoclimate Model, Geophys. Res. Lett., 29(23), 2102, doi:10.1029/2002GL015120, 2002.

J. C. Duplessy, M. Kageyama, D. Paillard, and G. Ramstein, Laboratoire des Sciences du Climat et l'Environnement, CE Saclay, L'Orme des Merisiers Bat. 709, F-19191 Gif Sur Yvette, France.

A. Ganopolski, Potsdam Institute for Climate Impact Research (PIK), P.O. Box 601203, D-14412 Potsdam, Germany.

M. Khodri, Lamont-Doherty Earth Observatory, Palisades, New York, USA. (khodri@1sce.saclay.cea.fr) 